\title{
Sosyal Bilgiler Öğretmenliği Öğrencilerinin Kahramanmaraş’ın Milli Tarih İçerisindeki Rolü ile İlgili Görüşleri ${ }^{1}$
}

\author{
Ahmet KAYA \\ Doç. Dr., Kahramanmaraş Sütçü İmam Üniversitesi, Eğitim Fakültesi \\ akaya574@hotmail.com \\ Orcid ID: https://orcid.org/0000-0001-8899-9178 \\ Sevda Gülşah YILDIRIM \\ Dr. Öğr. Üyesi, Kahramanmaraş Sütçü İmam Üniversitesi, Eğitim Fakültesi \\ sevdagulsah@gmail.com \\ Orcid ID: https://orcid.org/0000-0002-4278-6027
}

\begin{abstract}
Öz
Çalışma bir devlet üniversitesinin Sosyal Bilgiler Öğretmenliği Bölümü öğrencilerinin Kahramanmaraş'ın milli tarih içerisindeki rolü ile ilgili görüşlerini belirlemek amacıyla yapılmıştır. Araştırmada genel tarama modeli benimsenmiştir. Araştırmanın evreni, 2019-2020 Eğitim-Öğretim döneminde Eğitim Fakültesi Sosyal Bilgiler Öğretmenliği programına kayıtlı toplam 143 öğrencidir. Çalışmanın örneklemini ise evreni temsil ettiği düşünülen ve basit seçkisiz örneklemeye göre belirlenen 94 öğrenci oluşturmaktadır. Veriler, araştırmacılar tarafindan geliştirilen yazılı form ile toplanmıştır. Form, iki kısımdan oluşmaktadır. İlk kısımda hem katılımcıların demografik bilgilerini hem de Maraş'ın tarihi rolüne ilişkin bilgilerini belirleyen kısa cevaplı sorular; ikinci kısımda ise onların farkındalıklarını ortaya çıkarmak amaçlı yoruma dayanan uzun cevaplı sorular yer almaktadır. Kısa cevaplı sorular için frekans ve yüzde gibi betimsel istatistikler tercih edilirken yoruma dayalı sorularda soru içeriklerine bağlı kalınarak oluşturulmuş temalara göre analizler gerçekleştirilmiştir. Araştırma sonucunda öğrencilerin \%53'ünün Maraş'ın kaç yılında işgal edildiğini, \%75'inin Maraş'ın kimler tarafından işgal edildiğini, \%57'sinin Maraş'ın işgalinin ne kadar sürdüğünü 'bilmediği'; \%81 oranında öğrencinin ise konuyla ilgili herhangi bir etkinliğe katılmadığ tespit edilmiştir. Bulguların tamamı değerlendirildiğinde, öğrencilerin neredeyse yarısının
\end{abstract}

\footnotetext{
${ }^{1}$ Makale Geliş/Kabul Tarihi: 16.12.2019 / 10.03.2020

Künye Bilgisi: Kaya, A. ve Ylldırım, S. G. (2020). Sosyal Bilgiler Öğretmenliği Öğrencilerinin Kahramanmaraş'ın Milli Tarih İçerisindeki Rolü ile İlgili Görüşleri. Kahramanmaraşs Sütçü İmam Üniversitesi Sosyal Bilimler Dergisi, 17 (Özel Sayl), 144171. DOI: $10.33437 / k s u s b d .660249$
} 
Maraş'ın kurtuluş mücadelesinin milli tarih içerisindeki rolünün önemine ilişkin bilgilerinin yetersiz ve farkındalıklarının zayıf olduğu sonucuna ulaşılmıştır.

Anahtar Kelimeler: Milli Kimlik, Milli Şuur, Kahramanmaraş Kurtuluş Destan1.

\title{
Opinions of The Social Studies Teaching Students Related to The Role of Kahramanmaraş Within National History
}

\begin{abstract}
The research is to aim to determine the opinions of students enrolled Social Studies Teaching Department related to role of Kahramanmaraş in national history. General survey model preferred in this research. The population of the research are 143 students enrolled in Faculty of Education Social Studies Teaching Program in 2019-2020 academic years. The sample of the study are 94 students thought to represent the population and determined according to simple random sampling. Data was gathered through questionnaire developed by researchers. The questionnaire are two parts. In first part, there are the shortanswer questions determining participants' both knowledges concerning historical role of Maraş and demographic information; in the second part, there are the long-answer questions based on interpretation to reveal awareness of them. For the short-answer questions in the form, while descriptive statistical techniques such as percentage and frequency were preferred, in the questions based on interpretation, according to themes that was occurred by sticking to content of question were analyzed. In the result of research, it was revealed that 53 percent of students don't know answer relating what year Maraş was occupied, 75 percent of them don't know who was occupied by, 57 percent of them haven't knowledge about how long Maraş was under occupation and 81 percent of them don't participate any activity regarding the independence of Kahramanmaraş. When findings evaluate completely, it was reached results that nearly half of students about the role' important within national history of Maraş's struggle for liberation both have inadequate information and their awareness are poor.
\end{abstract}

Keywords: National Identity, National Consciousness, The Epic of Independence of Kahramanmaraş.

\section{GíRIŞ}

Son zamanlarda, milli kimlik / milli şuur ile ilgili değerlere karşı genç kuşakların ilgisizlikleri dikkat çekmektedir. $\mathrm{Bu}$ durum gelecek için endişe vericidir. Bir toplumun, ulus bilincini kazanması her şeyden önce "millı̂" 


\section{KSÜSBD Milli Mücadelenin 100. Yılında Kahramanmaraș Özel Sayısı}

değerlerinin benimsenmesiyle ilgilidir. Geçmiş tarihleri ile bağlarını koparan nesiller, gelecek kuşaklara güvenilir bilgi aktarımını yapma vazifesinde sorunlar yaşayacağı ve yaşatacağı için genç kuşaklarda sakat bir milliyetçilik anlayışının oluşmasına sebep olabilirler. Dolayısıyla bu nesiller, geçmiş ve gelecek arasında köprü vazifesi gören 'kültür' aktarımını bir sonraki nesle sağlıklı bir biçimde yapamayacakları gibi, sahip oldukları sakat bir milliyetçilik anlayışı nedeniyle de evrensel değerler arasında kendilerine yer edinemezler. Geçmiş ve gelecek arasındaki köprü konumundaki kültürün, gelecek nesle sağlam bir şekilde aktarılması ve vatan topraklarındaki daimiliğinin sağlanması ise kültürel kodlarımızı oluşturan de ğerler ve inançlarla mümkün olabilir. Bu sebeple sağlam bir tarih-kültür-inanç etkileşimi için, geleceğin en büyük emanetçileri olan öğrencilerimize öncelikle değerler ve inançlar temelinde sağlam bir millî kimlik / millî şuur kazandırılması gerektiği ifade edilebilir. Şimşek ve Ilgaz'a (2010) göre, "günümüzde ekonomik açıdan kapitalizm, siyasi açıdan demokrasi, hukuk açısından pozitif hukuk, kültürel açıdan türdeşleşmiş kültürler (ironik bir şekilde yerel kültürlerin de desteklendiği bir süreç) ve bireysel açıdan atomize olmuş bireylerin oluşumu ile ortaya çıkan bir düzeni ifade ettikleri ve küreselleşen sistem içerisinde yer bulan ulus-devlet ve onun oluşturduğu ulusal kimlik ve onun bireylere kazandirılması süreci sorgulanır ve tartışllı birer olgu olmuşlar/olmaktadırlar."

Yakın tarih sayılan “Türk Milli Kurtuluş Mücadele”sinin dönüm noktası olan "Kahramanmaraş Savunması"na ilişkin olarak yapılan bu araştırmada, araştırma kapsamında görüşlerine başvurulan ve gelecekte Sosyal Bilgiler Öğretmeni olarak Milli Eğitim Bakanlığı (MEB) bünyesinde görev yapacak aday öğretmenler olan öğrencilerin bu şanlı destana ilişkin sahip oldukları millî kimlik / millî şuur düzeylerinin düşük, bilişsel ve duyuşsal alanlardaki durumlarının yetersiz ve zayıf olduğunun tespit edilmesi araştırmacılar tarafından kaygı verici bir durum olarak değerlendirilmiştir. Araştırmayla öncelikle yetkilileri elde edilen bilimsel verilerle bilgilendirerek gerekli tedbirlerin alınması konusunda onları harekete geçirmek, öğrencilerin zihin dünyasında milli kimlik / milli şuur inşası sürecinde nelerin eksik kaldığı konusuna vurgu yaparak bu konuda yine yetkililer tarafından tez elden bir politika belgesinin oluşturulmasına ve uygulanmasına ön ayak olunması hedeflenmiştir.

\section{Milli Kimlik}

Millet, aynı dili konuşan, ortak bir maziye sahip olan ve gelecekte de birlikte yaşama arzusuna sahip insanların oluşturduğu bir topluluktur (Gözler, 2001). Milleti oluşturan fertlerin, bu birlikteliğinin devamı için kendi aralarında oluşturdukları milli kimlik bilincine sahip olmaları gerekmektedir. Milli kimlik, bir milletin kendine özgü düşünüş ve yaşayış biçimi, dil, töre ve gelenekleri, toplumsal değer yargıları ve kuralları ile oluşan özellikler bütünü, millî hüviyet 
olarak tanımlanmaktadır (sozluk.gov.tr, 2019). Milli kimliği "kolektif kültürel kimliğin bir türü" olduğunu vurgulayan Smith (2002), ayrıca ona göre milli kimliğin toplumsal bütünleşmeyi sağlayabilmesi için gereken özellikler ise şunlardır: ortak bir vatan toprağının varlığı, ortak bir tarih, ortak mitler ve tarihsel hafiza, bütün millet fertleri tarafından benimsenen kamu kültürü, millet fertlerinin tümünü kapsayan ortak yasal hak, görev ve sorumluluklar ve en son olarak da bireylerin serbestçe yapabildikleri ortak ekonomik faaliyetlerdir (Smith, 1991).

Tarih bireylerin kolektif belleğini şekillendirmede ve milli kimliğin inşasında en önemli araçlardan birisidir (Biletska, Şahin ve Şükür, 2014). Safran'a (2010) göre, tarih eğitiminin temel işlevleri olarak; milli bilinç inşası, toplumsal bütünlügün sağlanması için toplumun kültürel öğeleri olan milli ve manevi değerlerin geliştirilerek muhafazası, evrensel ölçekte de kültürel mozaiği kabul eden hoşgörülü fertler yetiştirmek sayılabilir. Dolayısıyla tarih eğitiminin örtük amaçlarından birisi de toplumda milli kimlik oluşturmaktır (Şıvgın, 2009). Bunu etkili bir şekilde başarabilmek için tarih öğretiminin de etkili bir şekilde yapılması gerekmektedir.

\section{Milli Şuur}

Milli birlik; milleti oluşturan farklı grup ve örgütlerin, ülke bekasını tehlikeye düşürecek durumlar karşısında güç birliği oluşturarak ve tehlikelere karşı ortak hareket etmeleridir. Öner'e (1986) göre böylesi bir durum en bariz şekliyle toplumun güç zamanlarında ortaya çıkar. Ayrıca böyle durumlarda milletin tamamımın görüşünü temsil eden milli zihniyet refleksiyle ortak akıl oluşur ve akabinde de milli şuur oluşumu gerçekleşir. Özetle bir milletin bekasını tehdit eden tehlikeler karşısında milli birlik şuurunun oluşarak milleti aksiyona sevk etmesine en iyi örnek, 1. Dünya Savaşı sonrası işgale karşı direniş ve Kurtuluş Savaşı olarak adlandırılan milli mücadele destanıdır.

Vatan, din, tarih, ahlâk vb. kolektif bir şuur ve devamında da eylem ortaya koymak için kullanılan değerlerdir (Öner, 1986). Eyleme milli bir karakter katmak için öncelikle kolektif bir şuur akabinde kolektif bir eylem devamında da kolektif bir bilinç gereklidir. Arsal'a (1972) göre milli bir karakter belli güçlükler karşısında ortak paydada buluşarak ortak hareket etme, aynı duyguları hissetme ve olaya aynı şekilde kıymet biçme eğiliminin bir yansımasıdır. Milli birlik şuurunun en somut örneği olarak ülke da çapındaki genel milli mücadele ve iller bazında sürdürülen özellikle Kahramanmaraş Kurtuluş Savaşına ilişkin milli mücadele süreci verilebilir. Bu mücadelenin sonucunda vatan toprakları kurtarılabilmiş̧ir. Milli şuur milletin ruhu gibidir ve daima diri tutulabilmesi için de sağlam bir tarih öğretimi gereklidir. 


\section{KSÜSBD Milli Mücadelenin 100. Yılında Kahramanmaraș Özel SayıSı}

\section{Milli Tarih Öğretimi}

Bir milletin belleği, tarihtir. Bir fert için hafiza ne ise, toplum içinde tarih odur. Hafiza kaybı yaşayan bir insanın hayatını istikrarlı bir şekilde sürdüremeyeceği gibi tarihini yeterince öğrenememiş ve özümseyememiş bir toplumun varlığını sürdürmesi zorlaşacaktır (Çakmak ve Bulut, 2013). Milletlerin hayatını insan hayatına benzeten İbn-i Haldun'a göre, milletlerin mevcudiyetlerini sağlıklı bir şekilde sürdürebilmeleri için sağlam bir tarih öğrenimi şarttır.

Tarih öğretiminin genel olarak amaçları: üyesi olduğu toplumun tarihi geçmişini tanıyarak kendine gelecekte buna göre yön vermek, farklı kültür ve coğrafyaları tanımak, fertlerin milli kimlik duygusunun gelişimine katkıda bulunmak olarak sayılabilir. Sungu (1927), tarih öğretiminden maksadın geçmişin öğrenilmesi ile sınırlı olmadığını ilk insandan günümüze gelinceye kadar insanlığın geçirdiği evrelerin iyi anlaşılmasını sağlayarak geleceğe yönelik bir nevi 1 şı tutmak olduğunu belirtmektedir. Ayrıca tarih, milli kimliğin oluşmasında da önemli bir rol üstlendiğinden (Akbaba, 2008) nasıl öğretileceği önemlidir.

Tarih öğretimi ile ilgili günümüzde yaşanan sorunlara genel olarak değinilecek olursa; tarih dersi, genelde soyut bilgi ve kavramların öğrenciye kazandırılması esasına dayanan yapısı itibari ile diğer bilim dallarından ayrılmaktadır. Tarihsel sürece ilişkin soyut kavramların öğrencilere kavratılması kadar onların çok boyutlu tarihsel olgu ve olaylara ilişkin değerlendirmeler ve yorumlar yapması da oldukça zordur (Bal, 2010). Baltacioğlu'na göre (Ata, 2000) öğretmeyi, belletmeyi, bilgi aktarmayı odağa alan gelenekselleşmiş öğretim anlayışı öğrencinin ruhuna hitap etmediği gibi toplumun ihtiyaçlarını da karşılamamaktadır

\section{Maraş’ın Kurtuluş Mücadelesinde Yeri}

I. Dünya Harbi'nde ittifak kuvvetleri ile aynı safta savaşa katılan Osmanlı Devleti de ittifak kuvvetlerinin yenilgisi neticesinde yenik devletler arasinda yerini almıştır. İngilizler, 30 Ekim 1918 tarihli Mondros Ateşkes Antlaşması'ndaki 7. maddeye dayanarak 22 Şubat 1919'da Maraş'1 işgal etmişlerdir. Maraş, İngilizlerin 1919 yılının Ekim ayı içerisinde bölgeyi Fransızlara devretmesiyle (Suriye İtilafnamesi Antlaşması) farklı bir işgal devleti ile karşı karşıya kalmıştır. Önce 29 Ekim 1919 tarihinde bir kısım Fransız birlikleri, sonrasında 30 Ekim 1919'da Fransız taburları ile birlikte şehre giren Ermeni lejyonları, Maraş'1 işgal etmişlerdir (Doğan, 2007; Ünalp, 2018). Hem bölücü faaliyet gösteren Maraş'ın içindeki Ermeniler hem de askeri birlik olarak şehre giren Ermeniler, daha işgalin ikinci gününden itibaren Müslüman kadınlara sataşmaya, sağa sola ateş açmaya, güvenliği bozucu faaliyetler göstermeye başlamışlardır. Bunun yanında karşı çıkan kim olursa öldürmekten geri 
kalmayarak birçok Müslüman'ı şehit etmişlerdir. Ermenilerin vahşeti giderek artmış, Müslüman erkekleri öldürüp kadınlara tecavüz etmişlerdir (Eyicil, 2003). Bunların yanında Fransızlar, Fransız üniforması giydirdikleri Ermenilere Türk evlerinin yağmalanmasını, yakılmasını ve katliam yapılmasını emretmişlerdir (Doğan, 2007).Yaşanan bu olaylara ilk tepki 31 Ekim 1919 tarihindeki Sütçü İmam veya Uzunoluk Vakası ${ }^{2}$ denilen olay ile gerçekleşmiştir. Daha sonra kaledeki Türk bayrağının indirilmesiyle meydana gelen 28 Kasım 1919 tarihli "Bayrak Olayı", Türk milletinin işgale direnişinin örnekleri olarak tarih sayfalarına yazılmışlardır (Eyicil, 2003). Fransız ve Ermeni mezalimlerinin giderek artması neticesinde 22 Ocak 1920 tarihinde savaş başlamış ve yaklaşık 20 gün süren savaşın sonunda Maraş, 12 Şubat 1920 tarihinde düşman işgalinden tamamen kurtulmuştur (Ünalp, 2018). Maraş'ın kurtuluşu, yalnızca bir şehrin düşman işgalinden kurtuluşu anlamına gelmemektedir. Maraş'ta Millî Mücadelenin ilk zaferi kazanılmıştır ve böylece Maraş zaferi devam eden bağımsızlık mücadelesine moral vermiştir. Farklı bir sonucun yol açacağı moralsizlik ve vazgeçmişliğin bütün bağımsızlık mücadelesine yaygın etkisi göz önüne alındığında, Maraş'ın milli tarih içerisinde rolünün önemi daha iyi kavranacaktır. Diğer taraftan Türk milletinin vatanseverliğini ve fedakârlığını göstermesi açısından da Maraş'ın önemi göz ardı edilmemelidir. Maraş'ın işgali sırasında düşman kuvvetlere karşı fedakârca mücadele eden birçok kahraman karşımıza çıkmaktadır. Daha önce de adından söz edilen Sütçü İmam, Kısaküreklerden Mehmet Ali Bey, Arslan Bey (Toğuzata), Mıllış Nuri, Abdal

\footnotetext{
${ }^{2}$ Ermeni askerlerden birisinin hamamdan çıkan bir Türk kadınına saldırarak peçesini yırtması ve "Artık burası Türklerin değildir. Fransız memleketinde peçe ile gezilmez" demesi üzerine olayı gören sütçülük ile geçinen ve adı İmam olan bir vatanseverin, kendi silahıyla Ermeni bir askeri öldürmesi olayıdır. Bu olayın hemen akabinde intikam almak isteyen Ermeniler, Sütçü İmam'ın akrabası olan Tiyekoğlu Kadir'in kulaklarını ve burnunu kesmiş, bütün azalarını vücudundan ayırarak şehit etmişlerdir (Ünalp, 2018: 215).

${ }^{3}$ Bu konuda farklı anlatımlar mevcuttur. Bir anlatıma göre, Fransız Yüzbaşısı Andre'nin davetine icabet etmeyenlere kızması sonrasında kaleden Türk Bayrağı indirilmiştir. Türk Bayrağının kalede dalgalanmadığını gören Kısaküreklerden Mehmet Ali Bey, Âlem-i İslam'a Hitap adıyla bir beyanname hazırlayarak bu yazısını birkaç camiye asmıştır. Cuma hutbesini okumak üzere minbere çıkan Ulu Cami imamı Rıdvan Hoca: "Hürriyeti olmayan bir milletin Cuma namazı kılması caiz değildir” demiştir. Bunun üzerine toplanan halk, kaleye tekrar Türk Bayrağını asmışlardır. Bayrağının asılmasını takriben kısa süren bir çatı̧̧ma yaşanmış ancak nihayetinde Cuma namazı, Türk Bayrağının gölgesinde kalede kılınmıştır (Kılınç, 2018: 177). Başka bir anlatıma göre ise Yüzbaşı Andre, Ermeni ileri gelenlerinden Hırlakyan'ın bir davetinde torununu dansa kaldırmış, ancak Helena 'ne Fransız ne de Ermeni bayrağı dalgalanmayan bir şehirde dans etmem' diyerek Yüzbaşıyı reddetmiştir. Bunun üzerine sinirlenen Yüzbaşı, kaledeki Türk Bayrağının indirilmesini emretmiştir (Ünalp, 2018: 216). Sonraki olaylar aynı şekilde devam etmektedir.
} 


\section{KSÜSBD Milli Mücadelenin 100. Yılında Kahramanmaraș Özel Sayısı}

Halil Ağa ${ }^{4}$,Aşıklığlu Hüseyin ${ }^{5}$, Rıdvan Hoca gibi halk kahramanları yanında Senem Ayşe, Bitlis Defterdarının eşi (Ünalp, 2018) gibi kadın kahramanlarında adını anmak gerekmektedir. Esasen bir kaynağa göre, milli mücadele döneminde Maraş, 344 şehit vermiştir (Kılınç, 2018: 183).

Kahramanmaraş'ın milli tarih içerisindeki en önemli rolleri arasında ilk sıralarda, İşgale karşı yerel direnişi sayesinde şehrin 1925 y1lında İstiklal Madalyasını ve 1973 yılında "Kahraman" unvanını alması (Ünalp, 2018: 230) gösterilebilir. Bu rolleri gelecek nesle aktarmak, farkındalıkları arttırmak, milli şuuru kazandırmak ve pekiştirmek amacıyla farklı senelerde farklı sanat türlerinde eserler meydana getirilmiştir. Bunlara bakıldığında romanlar, şiirler, tiyatro, destan, sinema, çizgi film gibi birçok alanda eserler karşımıza çıkmaktadır. Örneğin TRT tarafindan yayınlanan Muhteşem Türkler adlı çizgi film serisinin bir bölümünde Sütçü İmam'ın kahramanlığına ve Kahramanmaraş'ın düşman işgalinden kurtuluşuna yer verilmiştir (bkz. youtube.com/watch?v=YgB7c5QlVys\&t=1s, 2019). Bunun yanında Yücel Çakmaklı'nın yönetmenliğinde çekilen "Sahibini Arayan Madalya" adlı film, 1919 'da Maraş'ın düşman işgalinden kurtuluşunu ve İstiklal Madalyası almasına kadarki dönemde yaşanılanları konu edinmektedir. Aynı şekilde İstiklalden İstikbale Kahramanmaraş 12 Şubat Destanı adlı kısa film; yönetmenliğini Kerim Kabalcı'nın üstlendiği Kurtuluş Destanı adlı tiyatro eseri, Kahramanmaraş'ın kurtuluşunu konu edinen eserlere örnektir. Her ne kadar çizgi film, sinema, tiyatro gibi sanat dalları yönünden yeterli sayıda esere rastlanmamış olsa da Kahramanmaraş'ın kurtuluş mücadelesini konu edinen birçok şiir ve kitap (akademik veya roman) ile karşılaşlabilir. Esasen Kahramanmaraş, şairlerin şehri olmasıyla da ün salan bir ildir. Bunların yanında her sene Kahramanmaraş ilinde 12 Şubat gününde Maraş'ın kurtuluşu münasebetiyle ' 12 Şubat Kurtuluş Bayramı' etkinlikleri düzenlenmektedir. Söz konusu etkinliklerde kurtuluş mücadelesinde yaşanan olayların canlandırılması, mehteran yürüyüşü, yöresel çete kıyafetleriyle davul zurna eşliğinde şehir içinde yürüyüşler gibi faaliyetler gerçekleştirilmektedir (“www.kahramanmaras.bel.tr”).

Milli tarihin öğrenilmesinde ve milli bilincin kazanılmasında müzelerin ve ören yerlerinin önemi yadsınamaz. Esasen kültür ve tabiat varlıklarına yönelik bir

\footnotetext{
${ }^{4}$ Fransız işgal birliklerini görkemli bir törenle karşılamak isteyen Ermeniler, Abdal Halil Ağa'ya giderek adamlarıyla beraber karşılama töreninde davul çalmasını isterler. Abdal Halil Ağa bu teklif karşısında "Değil bir kese altın davulumun kasnağını altınla doldursanız ben din kardeşlerimin bağrına çomağımı vurmam!" diyerek reddeder. Abdal Halil Ağa, işgale karşı duruşun sembollerinden biri haline gelmiştir (ansiklopedi.46.web.tr, 2019).

5“"Maraş bize yar olmadan, düşmana gülzar olmaz" sözünü söylediği öne sürülen, kurtuluş mücadelesinin kahramanlarından biridir. Aşıklığlu Hüseyin ile ilgili ayrıntılı bilgilere, Mehmet Işık’ın "Aşıklıoğlu Hüseyin” adlı kitabından ulaşılabilir.
} 
bilincin gelişmesinde müze ve ören yerlerinin eğitimsel amaçla kullanımının önemi giderek anlaşılmaktadır (Ata, 2015). Bu amaç üzerinden bakıldığında, öğretmenlerin müze ve ören yerlerine ilişkin bilinci öncelikle kendilerinin kazanmasını, başka bir ifadeyle müze ve ören yerlerine ilgi göstermelerini, bulundukları yerdeki müze ve ören yerlerini bilmelerini ve ziyaret etmelerini beklemek doğal karşılanabilir. Kahramanmaraş söz konusu açıdan kabul edilebilir bir müzecilik anlayışına sahiptir. İl Kültür ve Turizm Müdürlügü’nün verilerine göre, Kahramanmaraş il merkezinde toplam on müze (Kahramanmaraş Arkeoloji Müzesi, Yedi Güzel Adam Edebiyat Müzesi, Etnografya Müzesi, Tematik Mutfak Müzesi, Dondurma Müzesi, Somut Olmayan Kültürel Miras Müzesi, Minyatür Kurtuluş Müzesi, Dijital Kurtuluş Müzesi, Kurtuluş Destanı Panorama Müzesi, Eğitim Tarihi Müzesi) ve bir ören yeri (Germanicia Ören Yeri) bulunmaktadır (kahramanmaras.ktb.gov.tr, 2019).

\section{Araştırmanın Amacı}

Tarihin geçmişteki olayları neden sonuç ilişkisini içerisinde analiz etmek gibi genel geçer tanımının yanında milli kimlik edinimini sağlamak, kültürel miras ve değerleri nesilden nesile aktarmak gibi amaçları da mevcuttur (Kaya, 2015). Okulda sözü edilen amaçları gerçekleştirecek yürütücü kuvvet ise öğretmendir. Öğretmenlerin yaşamlarını idame ettirdikleri çevrelerinin milli tarihine ilişkin bilgi ve farkındalık düzeyleri, bu noktada önem arz etmektedir. Sosyal Bilgiler Öğretmenliği Programı ise tarih disiplininin ağırlıklı olduğu öğrenme alanları itibariyle ilkokul ve ortaokul öğrencilerine milli bilincin, milli kimliğin ve kültürel değerlerin aktarımında öncelikli bir ders olarak karşımıza çıkmaktadır (Millî Eğitim Bakanlığ1 -MEB-, 2005; 2018). Sosyal bilgiler dersinin içeriklerinin yakından uzağa ve genişleyen çevre ilkelerine göre hazırlandığı göz önüne alındığında, milli kimliğin ise öncelikle yakın çevrenin milli tarihini bilmekle ve bulunulan çevrenin milli tarih içerisindeki rolünün farkında olmakla kazandırılabilec eği söylenebilir. Buradan hareketle, mevcut araştırmanın amacı, Sosyal Bilgiler Öğretmenliği Programında öğrenim gören öğrencilerin, Kahramanmaraş'ın milli tarih içerisindeki rolüne ilişkin bilgilerini ve farkındalıklarını ortaya koymaktır. $\mathrm{Bu}$ amaç doğrultusunda aşağıdaki sorulara cevaplar aranmıştır:

1) Sosyal Bilgiler Öğretmenliği Programında öğrenim gören öğrencilerin Kahramanmaraş'ın milli tarih içerisindeki rolüne ilişkin bilgileri ne düzeydedir?

2) Sosyal Bilgiler Öğretmenliği Programında öğrenim gören öğrencilerin Kahramanmaraş'ın milli tarih içerisindeki rolüne ilişkin farkındalıkları ne düzeydedir? 


\section{KSÜSBD Milli Mücadelenin 100. Yılında Kahramanmaraș Özel Sayısı}

3) Sosyal Bilgiler Öğretmenliği Programında öğrenim gören öğrencilerin Kahramanmaraş'ın milli tarih içerisindeki rolüne ilişkin bilgi ve farkındalığın arttırılması için tavsiyeleri nelerdir?

\section{YÖNTEM}

Bu bölümde araştırmanın model, evren ve örneklem, veri toplama aracı ve verilerin analizi kısımlarına yer verilecektir.

\section{Model}

Araştırmada nicel araştırma yöntemlerinden genel tarama modeli benimsenmiştir. Bu türlü araştırmalarda, halen var olan bir durum, var olduğu şekliyle tespit edilmeye çalışılır. Tarama araştırmalarında nedir veya nelerdir sorularıyla sıç̧a karşılaşı1ır (Karasar, 2019). Aynı zamanda tarama çalışmaları, bireylerin tutumlarını, eylemlerini, fikirlerini ve inançlarını belirleme ihtiyacı duyulduğunda tercih edilebilecek bir yöntemdir (Christien, Johnson ve Turner, 2015). Araştırma, öğrencilerin Kahramanmaraş'ın milli tarih içindeki rolüne ilişkin bilgilerini ve farkındalıklarını olduğu gibi ortaya koymayı amaçlamaktadır. $\mathrm{Bu}$ noktadaaraştırma için en uygun modelin genel tarama olduğu görülmüştür.

\section{Evren ve Örneklem}

Araştırmanın evrenini bir devlet üniversitesinde 2019-2020 Eğitim-Öğretim döneminde sosyal bilgiler öğretmenliği programına kayıtlı toplam 143 öğrenci oluşturmaktadır. Çalışmanın örneklemini ise evreni temsil ettiği düşünülen ve seçkisiz örnekleme yöntemlerinden basit seçkisiz örneklemeye göre belirlenen 94 öğrenci oluşturmaktadır. Örneklemin demografik özelliklerine ilişkin sınıf düzeyi ve cinsiyet bilgileri, tablo 1'de sunulmaktadır.

Tablo 1. Kat1lımcılara Ait Cinsiyet Ve Sınıf Düzeyi Bilgileri

\begin{tabular}{l|cccc}
$\begin{array}{r}\text { Sinıf } \\
\text { Düzeyi }\end{array}$ & 1. sinıf & 2. sinıf & 3. sinıf & Toplam \\
Cinsiyet & & & & \\
\hline $\begin{array}{l}\text { Kız } \\
\text { ögrenci }\end{array}$ & 17 & 25 & 20 & 62 \\
$\begin{array}{l}\text { Erkek } \\
\text { ögrenci }\end{array}$ & 8 & 10 & 14 & 32 \\
Toplam & 25 & 35 & 34 & 94 \\
\hline
\end{tabular}


Tablo 1 incelendiğinde, katılımcıların \%66'sının ( $\mathrm{n}=62)$ kız öğrenci olduğu, \%34'ünün $(\mathrm{n}=32)$ olduğu görülmektedir. Ayrıca araştırmaya katılan öğrencilerin $\% 27$ 'si $(n=25)$ birinci sınıf, \%37'si $(n=35)$ ikinci sınıf, \%36's1 $(n=34)$ üçüncü sınıfta öğrenim görmektedir. Bu bilgiler yanında öğrencilerinin yaş aralığının 18 ile 22 arasında (bir öğrenci hariç) olduğu bulunmuştur. Ailelerinin ikamet ettiği yere ilişskin elde edilen verilere göre ise katılımcıların yarısından çoğunun (\%51, $\mathrm{n}=48$ ) Kahramanmaraş'ta yaşadığı, bu kişilerin büyük çoğunluğunun $(\mathrm{n}=32)$ ise merkez ilçelerde ikamet ettiği görülmüştür. Katılımcıların \%49'u $(n=46)$ ise farklı bir ilden öğrenim görmek amacıyla Kahramanmaraş'a gelen öğrencilerdir. Anne ve baba mesleklerine ilişkin bilgilere bakıldığında ise öğrencilerin üçünün babasının herhangi bir işte çalışmadığı, bir öğrencinin babasının vefat ettiği, geri kalan 90 öğrencinin ise babalarının farklı meslek gruplarında yer aldığ 1 bulunmuştur. Anne mesleklerine ilişkin veriler incelendiğinde ise öğrencilerin 86'sının annesinin herhangi bir işte çalışmadığı görülmüştür. Bu sayı, bir hayli fazla görünmektedir. Gelir dağılımı sorusuna ilişkin katılımcılardan 13'ü herhangi bir yanıt vermezken, kalan 81 öğrenci üzerinden hesaplanan aile gelir ortalaması ise 2,800 TL olarak bulunmuştur. Çalışmaya katılan öğrencilerin demografik bilgileri incelendiğinde özetle, katılımcıların büyük çoğunluğunun kız öğrencilerden oluştuğu, genç nüfus arasında yer aldıkları, çoğunun ailesi ile birlikte Kahramanmaraş'ta yaşadığı, gelir durumu bakımından yoksulluk sınırı altında bir gelire sahip oldukları, annelerin büyük oranda ev hanımı olması ve babanın çalışması açısından geleneksel ataerkil aile yapısına sahip oldukları söylenebilir.

\section{Veri Toplama Aracı}

Veriler, araştırmacılar tarafindan geliştirilen yazılı form ile toplanmıştır. Araştırmacılar, öncelikle literatüre dayalı olarak taslak soruları hazırlamıştır. Hazırlanan taslak form, sosyal bilgiler eğitimi alanında uzman iki öğretim üyesi ve eğitim bilimleri alanında uzman iki öğretim üyesi olmak üzere toplam dört alan uzmanına sunulmuştur. Uzmanlardan gelen dönütlere göre forma son şekli verilerek veri toplama çalışmalarına başlanmıştır. Nihai form, iki kısımdan oluşmaktadır. İlk kısımda hem katılımeıların demografik bilgilerini hem de Maraş'ın tarihi rolüne ilişkin bilgilerini belirleyen kısa cevaplı sorular, ikinci kısımda ise farkındalıklarını ortaya çıkarmak amaçlı yoruma dayalı uzun cevaplı sorular yer almaktadır. Veriler, araştırmacı tarafindan bizzat toplanmıştır.

\section{Verilerin Analizi}

Mevcut araştırmada elde edilen veriler, nicel araştırmaların doğasına uygun olarak tümdengelim analiz yöntemi ile çözümlenmiştir. Formda yer alan kısa cevaplı sorular için frekans ve yüzde gibi betimsel istatistikler tercih edilirken yoruma dayalı sorularda soru içeriklerine bağlı kalınarak oluşturulmuş temalara 


\section{KSÜSBD Milli Mücadelenin 100. Yılında Kahramanmaraș Özel Sayısı}

göre analizler gerçekleştirilmiştir. Bununla birlikte uzun cevaplı sorulardan elde edilen bazı verilerin anlamını güçlendirmek amacıyla frekans değerleri verilmiştir. Açık uçlu sorulardan elde edilen verilerin analizinin güvenirliğini sağlamak amacıyla veriler, iki araştırmacı tarafindan ayrı zamanlarda kodlanmış ve kodlar, daha önceden belirlenen temaların altına sınıflandırılmıştır. Herhangi bir tema altında yer almayan bir kod ile karşılaşıldığında ise tema önerilmiştir. Daha sonra ortaya çıkan temalar (varsa önerilen tema ile birlikte) ve kodlar karşılaştırılmıştır. Görüş ayrılığı olan kod ve temalar üzerine araştırmacılar, bilimsel tartışma yaparak ortak görüşe ulaşmışlardır. Ortak karar sonrasında nihai kod ve temalara ulaşılmışıı. Araştırmada, belirlenen kod ve temaların anlamını kuvvetlendirmek amacıyla doğrudan alıntılara da yer verilmiştir. Bu sebeple her bir katılımciya kod isim verilmiştir. Örneğin K1S1 kodlamasında K1, birinci katılımc1 olduğunu, S1 ise sosyal bilgiler öğretmenliği birinci sınıf öğrencisi olduğunu göstermektedir.

\section{BULGULAR VE YORUM}

Çalışmanın bu kısmında, araştırma sorularına yönelik elde edilen bulgulara yer verilmiştir.

1) Sosyal Bilgiler Öğretmenliği Programında öğrenim gören öğrencilerin Kahramanmaraş'ın milli tarih içerisindeki rolüne ilişkin bilgileri ne düzeydedir? sorusuna ilişkin bulgular:

Katılımcılara Kahramanmaraş'ın milli tarih içerisindeki rolüne ilişkin bilgi temelli sorular yöneltilmiştir. Sözü edilen sorulara verilen cevaplara ilişkin bulgular aşağıda maddeler halinde sıralanmıştır.

- Maraş'ın kaç yılında işgal edildiğine ilişkin katılımcıların \%53'ü (n=50) cevabı 'bilmediğini' ifade etmiştir. Bilmiyorum cevabı veren öğrencilerin 24'ünün ise ailesinin Maraş'ta yaşadığ 1 görülmüştür. Katılımcıların \%20'si $(n=19) 1920$ cevabını verirken, \%10’u (n=9) 1918 diye belirtmiştir. Öğrencilerin yalnızca \%11'i $(n=10) 1919$ diyerek doğru cevabı vermiştir. Kalan altı öğrenci ise 1912, 1973, 1925 gibi farklı cevaplar vermişlerdir. Doğru cevap üzerinden farklı değişkenlere göre karşılaş̧ırma yapıldığında, birinci sınıfta öğrenim gören 25 öğrenciden yalnızca 3'ü; üçüncü sınıfta öğrenim gören 34 öğrenciden yalnızca 5'i doğru cevabı vermiş, ikinci sınıfta öğrenim gören 35 öğrenciden hiçbiri doğru cevabı vermemiştir. Cinsiyet değişkeni açısından karşılaştırıldığında, doğru cevab1 veren öğrencilerinin 7'sinin erkek, 3'ünün k1z öğrenci olduğu görülmektedir. Ailelerin yaşadıkları illere göre cevaplar karşılaştırıldığında, Maraş’ta yaşayan 48 öğrenciden yalnızca dört öğrencinin (\%8) 1919 diyerek doğru cevabı verdiği görülmüştür. Başka bir ifadeyle ailesiyle birlikte Maraş’ta yaşayan \%92 öğrenci, Maraş'ın hangi yılda işgal edildiğini bilmemektedir. 
- Maraş’1 kimlerin işgal ettiğine dair bilgilerin sorulduğu soruların cevaplarına bakıldığında, dört öğrenci (\%4) cevabı bilmediklerini, öğrencilerin büyük bir çoğunluğunun $(\mathrm{n}=52, \% 55)$ ise Fransızlar şeklinde cevap verdikleri görülmüştür. 23 öğrenci (\%25) İngilizler ile Fransızlar; 9 öğrenci (\%10) Fransızlar ile Ermeniler; 4'ü (\%4) yalnızca İngilizler; 2'si (\%2) İngilizler, Fransızlar ve Ermeniler tarafından Maraş'ın işgal edildiğini belirtmiştir. Maraş'ı öncelikle İngilizler işgal etmiş, sonrasında Fransızlara devretmişlerdir. Fransızlar kuvvetleri arasında Ermeni lejyonlar yer almıştır ancak bununla birlikte işgal devleti olarak Ermenilerin Maraş'1 işgal ettiği söylenemez. Bu bulgulara göre öğrencilerin yalnızca yirmisinin doğru cevabı verdiği söylenebilir. Diğer bir ifadeyle katılımcıların \%75'inin Maraş'ın kimler tarafından işgal edildiğini bilmediği sonucu çıkmaktadır. Ayrıca, öğrencilerin büyük bir çoğunluğu her iki işgal kuvvetini öncelik sonralık belirtmeksizin aynı sırada belirtmişlerdir. Önce İngilizler sonrasında Fransızlar gibi bir cevap yalnızca bir öğrenciden gelmiştir. Doğru cevap üzerinden farklı değişkenlere göre karşılaştırma yapıldığında, birinci sınıfta öğrenim gören 25 öğrenciden yalnızca 5'i; ikinci sınıfta öğrenim gören 35 öğrenciden yalnızca 9'u; üçüncü sınıfta öğrenim gören 34 öğrenciden ise yine yalnızca 9'u doğru cevabı vermiştir. Cinsiyet değişkeni açısından karşılaştırıldığında, doğru cevabı veren öğrencilerinin 11'inin erkek, 12'sinin kız öğrenci olduğu görülmektedir. Ailelerin yaşadığı il değişkeni açısından incelendiğinde, Maraş'ta yaşayan 48 öğrenciden 15'inin (\%31) Maraş'ın kimler tarafından işgal edildiği bilgisine sahip olduğu görülmektedir. $\mathrm{Bu}$ oranlara bakıldığında, Maraş’ta yaşayan öğrencilerin kendi yerel tarihlerine ilişkin bilgilerinin zayıf olduğu söylenebilir.

- Maraş'ın işgalinin ne kadar sürdüğüne ilişkin soruya 54 öğrenci (\%57) 'bilmiyorum' cevabını vermiştir. Bilmiyorum cevabı veren öğrencilerin 25'inin ise ailesinin Maraş'ta yaşadığ görülmüştür. Maraş, 22 Şubat 1919'dan 12 Şubat 1920'ye kadar işgal altında kalmıştır. Tarihsel olarak işgal zamanlarını 1 yıl, yaklaşık 1 yıl veya 12 ay olarak belirten bütün cevaplar doğru kabul edilmiştir. Bununla birlikte öğrencilerin yalnızca 10'unun (\%11) doğru cevabı verdiği görülmüştür. Kalan 30 öğrencinin (\%32) ise çok farklı tarihler beyan ettiklerine rastlanılmıştır. Sözü edilen öğrenciler, İ̧̧gal süresini 15 gün, 21 gün, 8 ay, 2 yıl veya 3 yıl olarak belirtmiş̧lerdir. Bulgular arasından en ilgi çekenler ise Maraş'ın işgal süresine 5 veya 10 yıl olarak cevap verenlerdir. Kurtuluş Savaşı'nın resmi olarak başlangıç ve bitiş süresi göz önüne alındığında bile 5 veya 10 yıl cevabının verilmemesi gerektiği aşikârdır. Buradan hareketle, öğrencilerin çoğunun sadece Maraş'ın tarihi ile ilgili değil, genel milli tarih bilgilerinin de zayıf olduğu sonucuna ulaşılabilir. Çeşitli değişkenler açısından doğru cevap verenler karşılaştırıldığında, birinci sınıfta öğrenim gören 25 öğrenciden yalnızca 3’ü; ikinci sınıfta öğrenim gören 35 öğrenciden yalnızca 1'i; üçüncü sınıfta öğrenim gören 34 öğrenciden ise yalnızca 6'sı doğru cevabı vermiştir. Cinsiyet değişkeni açısından karşılaştırıldığında, doğru cevabı veren öğrencilerinin 7'sinin erkek, 
3’ünün kız öğrenci olduğu görülmektedir. Ailelerin yaşadığı il değişkeni açısından incelendiğinde, Maraş'ta yaşayan 48 öğrenciden 5'inin (\%10) Maraş'ın ne kadar süre işgal altında kaldığı bilgisine sahip olduğu görülmektedir. Bulguların geneline bakıldığında öğrencilerin tarih bilgilerinin zayıf olduğu söylenebilir.

2) Sosyal Bilgiler Öğretmenliği Programında öğrenim gören öğrencilerin Kahramanmaraş'ın milli tarih içerisindeki rolüne ilişkin farkındalıkları ne düzeydedir? sorusuna ilişkin bulgular:

Katılımcılara Kahramanmaraş'ın milli tarih içerisindeki rolüne ilişkin bilgi temelli sorular yöneltilmiştir. Sözü edilen sorulara verilen cevaplara ilişkin bulgular aşağıda maddeler halinde sıralanmıştır.

- Öğrencilerden yalnızca 18’i (\%19) Maraş’ın kurtuluşu ile ilgili bir etkinliğe katıldığını belirtmiştir. Kalan 76 öğrenci ise hiçbir etkinliğe katılmadıklarını söylemiştir. Bu öğrencilerin 14'ü Maraş'ta ikamet ederken diğer 4 öğrenci ise farklı illerden gelmişlerdir. Farklı illerden gelen öğrenciler de dahil olmak üzere Maraş'ın kurtuluşuna dair bir etkinliğe katılan öğrencilerin çoğu $(\mathrm{n}=15)$ ikinci ve üçüncü sınıfta öğrenim görmektedirler. Araştırmacıların katıldığı etkinliğin ise '12 Şubat Kurtuluş Bayramı' etkinlikleri olduğu verilen cevaplardan anlaşılmaktadır.

- Öğrencilerin Maraş’ın kurtuluşu ile ilgili bilgileri en çok okuldan ( $f=61)$, sirasiyla aileden $(f=31)$, sosyal çevreden $(f=25)$, sosyal medyadan $(f=17)$, üniversiteden ( $f=11)$, basından $(f=8)$, belediye etkinliklerinden $(f=7)$ öğrendikleri görülmüştür. Bunlar dışında müze gezilerinden de $(f=3)$ öğrendiğini belirten öğrencilere rastlanmıştır. Okulda genellikle tarih disiplini içerikli derslerden veya ders kitaplarından edinildiği belirtilmiştir. Bilgi içerikli sorulara verilen yanttlara ilişkin bulgularla birlikte ele alındığında, okulda öğrenilen bilgilerin kalıcılığının sorgulanmas1 gerektiği söylenebilir. K16S1 kodlu öğrenci "Okullarda ders içeriklerinde anlatıldı fakat aklımda kalmasını sağlayacak kadar değil" diyerek söz konusu yorumu desteklemektedir. Arkadaş çevresi, sokak adlarından vb. ifadeler ise sosyal çevreye dahil edilmiştir. K41S2 kodlu öğrenci bu konuda "Yerlere ve bölgelere verilen isimler bir hikâye ve geçmişi sezdiriyor" diyerek sokak adlarının bile tarihi bilgileri öğrenme merakı oluşturduğuna dikkat çekmiştir.

- Öğrencilere okulda yapılan Maraş'ın kurtuluşuna yönelik etkinliklerden hafizasında kalanlar sorulmuştur. İfade sıklığına göre sırasıyla öğrenciler, tiyatro gösterimi $(f=22)$, şiir okuma etkinliği $(f=22)$, metin, destan vb. okuma etkinliği $(f=4)$, günün anlam ve önemine dair öğretmenlerin konuşmaları $(f=4)$, çete kıyafetleri ile yürüyüş yapmak $(f=4)$, drama/canlandırma etkinliği $(f=3)$, folklor 
oyunları $(f=2)$, kısa film gösterimi $(f=1)$, koro halinde okunan şarkılar $(f=1)$ gibi etkinliklerin hafızalarında kaldığını belirtmişlerdir. Elde edilen bulgulara göre, öğrenciler en fazla tiyatro gösterimini ve şiir okuma etkinliklerini; en az ise folklor, kısa film gösterimi ve koro etkinliklerini hatırlamaktadırlar. Konuyla ilgili K86S3 "O dönemde yaşanan olayları tiyatro şeklinde bize yansıtmaları ve büyük coşkuyla kutlamaları aklımda kaldr.” Diyerek tiyatronun etkisini vurgulamıştır. Bununla birlikte 94 öğrenciden 54'ü soruyu ya boş bırakmış ya da soruya 'hatırlamıyorum' cevabını vermiştir. Hatırlamadığı yönünde cevap veren K27S2 kodlu öğrenci, "Hiçbir şey kalmadı aklımda çünkü bu tür etkinlikler hiç denecek kadardl." şeklinde görüş bildirirken, K73S3 kodlu öğrenci ise "12 Şubat'ta pek etkinlik yapılmadı okulumuzda. Hatta hiç olmadl. Genelde şehir genelinde kutlamalar yapıldı" demiştir. Öğrencilerin yaşları itibariyle bazı etkinlikleri tam olarak hatırlamamaları normaldir. Ayrıca öğrencilerden 46'sının farklı illerden geldiği göz önüne alınırsa söz konusu cevaplara ilişkin ortaya çıkan sayının yüksekliği doğal karşılanabilir. Ancak yine de diğer etkinliklere nazaran tiyatro gösterimi ve şiir okuma etkinliklerinin hafizalarda daha çok yer edinmesi, dikkate değer bir bulgudur.

- Öğrencilerin farkındalıklarını ortaya çıkarmak amacıyla Maraş'ın kurtuluşu ile ilgili çeşitli görsel sanat aktivitelerine (tiyatro, film, çizgi film, müze gezisi) katılıp katılmadıkları ve çeşitli edebi türleri (kitap, şiir) okuyup okumadıklarına dair sorulara verilen yanıtlar karşılaştırmalı olarak tablo 2'de görülmektedir.

Tablo 2. Maraş'ın Kurtuluşu İle İlgili Yazılı Ve Görsel Eserlere Yönelik Öğrenci Cevaplarının Karşılaştırmalı Dağılımı

\begin{tabular}{|c|c|c|c|c|c|c|c|c|c|c|c|c|}
\hline Sinif & \multicolumn{4}{|c|}{ 1. SINIF } & \multicolumn{4}{|c|}{ 2. SINIF } & \multicolumn{4}{|c|}{ 3. SINIF } \\
\hline Cinsiyet & \multicolumn{2}{|c|}{$\mathbf{K}$} & \multicolumn{2}{|c|}{$\mathbf{E}$} & \multicolumn{2}{|c|}{$\mathbf{K}$} & \multicolumn{2}{|c|}{$\mathbf{E}$} & \multicolumn{2}{|c|}{$\mathbf{K}$} & \multicolumn{2}{|c|}{$\mathbf{E}$} \\
\hline $\begin{array}{l}\text { Katıldım/ } \\
\text { Okudum }\end{array}$ & Evet & Hayr & Evet & Hayr & Evet & Hayrr & Evet & Hayrr & Evet & Hayr & Evet & Hayir \\
\hline Kitap & - & 17 & - & 8 & 1 & 24 & - & 10 & - & 20 & 2 & 12 \\
\hline Şiir & - & 17 & - & 8 & 6 & 19 & 1 & 9 & 5 & 15 & - & 14 \\
\hline Tyatro & 1 & 16 & 3 & 5 & 3 & 22 & 2 & 8 & 5 & 15 & 2 & 12 \\
\hline Film & - & 17 & 2 & 6 & 1 & 24 & 2 & 8 & 4 & 16 & - & 14 \\
\hline Çizgi Film & - & 17 & 2 & 6 & 1 & 24 & - & 10 & - & 20 & 2 & 12 \\
\hline $\begin{array}{l}\text { Müze } \\
\text { Gezisi }\end{array}$ & 10 & 7 & 6 & 2 & 7 & 18 & 8 & 2 & 16 & 4 & 12 & 2 \\
\hline
\end{tabular}

Tablo genel olarak incelendiğinde, öğrencilerin diğer faaliyetlerden ziyade müze ziyaretlerine aktif olarak katıldıkları; sınıf düzeyi arttıkça etkinliklere katılım oranlarının arttığı söylenebilir. Her ne kadar cinsiyet değişkeni açısından kız öğrencilerin erkek öğrencilere göre daha katılımcı olduğu görülse de böyle bir yorum, katılımcı sayısındaki eşitsizlik sebebiyle pek doğru olmayabilir. Tablo 


\section{KSÜSBD Milli Mücadelenin 100. Yılında Kahramanmaraș Özel Sayısı}

ayrı birimler halinde değerlendirildiğinde ise 94 öğrenciden 91'i (\%97) Maraş'ın kurtuluşu ile ilgili kitap okumadığını belirtmiştir. Yalnızca üç öğrenci bu konuda kitap okumuştur. Şiir türünde ise okuyan sayısında az da olsa bir artış $(n=12)$ gözlenmiştir. Bununla beraber 82 öğrenci (\%87) Maraş’ın kurtuluş mücadelesi ile ilgili şiir okumadığını belirtmiştir. Görsel sanatlar dalında yeterli sayıda eser olmasa bile, yine de var oldukları bilinmektedir. Öğrencilerin bu alanda da zayıf bir tutum sergiledikleri söylenebilir. Maraş'ın kurtuluşu ile ilgili tiyatro izleyen öğrenci sayısının toplam 16 (\%17); film izleyen öğrenci sayısının 9 (\%10); çizgi film izleyen öğrenci sayısının 5 (\%5) olduğu görülmektedir. Kahramanmaraş’ta bulunan müze ve tarihi mekânların ziyaret edilmesi noktasında ise öğrencilerin daha aktif olduğu açıç̧a görülebilmektedir. 94 öğrenciden 59'u (\%63) en az bir müze veya tarihi mekân gezisine katılım göstermiştir. Etkinliklerin tamamı değerlendirildiğinde, öğrencilerin Maraş'ın kurtuluş mücadelesinin milli tarih içerisindeki rolünün önemine ilişkin farkındalıklarının yetersiz olduğu söylenebilir.

- Maraş halkına işgal dönemindeki mezalimler hakkında görüş ve bilgilerinin sorulduğu soruya ilişkin verilen cevaplar kullanım sıklığına göre yapılan mezalimler, kadınlara taciz $(f=20)$, halka zulüm $(f=16)$, halkın malını yağmalama/malına zarar verme $(f=9)$, halka şiddet uygulama $(f=8)$, milli ve dini duygulara saygısızlık $(f=7)$, halkın yaşayışına müdahale etme $(f=7)$, sivil halka işkence $(f=7)$, halka baskı ve tehdit $(f=7)$, sivil halkı öldürme $(f=6)$, halkı aşağılama/köle gibi görme $(f=4)$ ve tecavüz $(f=4)$ şeklinde sıralanabilir. Bununla birlikte 94 öğrenciden 46'sı söz konusu soruya 'bilmiyorum' cevabını vermiştir. Öğrencilerin neredeyse yarısının (\%49) milli tarih konusunda farkındalıklarının zayıf olduğu söylenebilir.

- Maraş'ın kurtuluşunda adı geçen tarihi şahsiyetlerin kimler olduğu sorusuna ilişkin öğrencilerin cevaplarında neredeyse bütün kahramanların adlarına rastlanmıştır. En sık bahsedilen kahraman Sütçü İmam ( $f=79)$ olmuştur. Bunun sebeplerinden biri olarak Kahramanmaraş'ta bulunan bir devlet üniversitesinin adı olmasının etkisi gösterilebilir. Sütçü İmam'ın kahramanlığı ile ilgili K61S3 kodlu öğrenci "Hamamdan çıkan kadınların başörtüsüne el sürmeye çalışan Fransız askerini vurarak büyük bir direnişin başlamasına öncülük etmiştir." şeklinde cevap vermiştir. Adından bahsedilen diğer kahramanlar sirasiyla Ridvan Hoca $(f=15)$, Senem Ayşe $(f=8)$,Abdal Halil Ağa $(f=8)$, Arslan Bey $(f=4)$, Mıllış Nuri( $(f=1)$, Aşıklığlu Hüseyin $(f=1)$ ' dir. Öğrencilerden K80S3 kodlu öğrenci Rıdvan Hoca'nın kahramanlığını "Bayrak olayı. Cuma namazında kalede Fransız bayră̆ı asıldı̆̆ı için namazı kıldırmamıştır" sözleriyle dile getirirken K33S2 kodlu öğrenci Aşıklığlu Hüseyin'i "Kalemizde yazılı olan 'Maraş bize mezar olmadan düşmana gülzar olmaz' sözünü düşmana karşl söyleyen halk kahramanı" olarak belirtmiştir. Bununla birlikte 13 öğrenci ya soruyu boş bırakmış ya da bilmiyorum cevabını vermiştir. 
- Maraş'ın kahraman unvanını neden aldığına ilişkin soruya öğrencilerin genellikle benzer cevap verdikleri görülmüştür. İfade edilme sıklıklarına göre öğrenci cevaplarına bakıldığında; "Yerel halkın ve Kuvây-1 Milliye'nin topyekûn mücadele ederek zafer kazanması $(f=31)$ ", "Halkın Fransızlara karşı direnişi $(f=30)$ ", "Maraş halkının kendi imkânlarıyla direniş göstermesi $(f=19)$ ", "Halkın mücadele sırasında evlerini yakmaya varan fedakârlıkları $(f=4)$ " ş̧eklinde nedenler belirttikleri bulunmuştur. Halkın topyekûn mücadelesiyle ilgili K75S3 kodlu katılımcı "Maraş ili kuşatmalara boyun eğmeyerek yaşlı, genç, kadın, erkek, çocuk ayırmaksızın bütün halkiyla işgal kuvvetlerine karşı durdu. Bu inanılmaz direnişin sonucunda yeniden bağımsızlı̆̆ına kavuştu ve Meclis tarafindan 'Kahraman' unvan ile ödüllendirildi.” demiş̦tir. Bununla birlikte 13 öğrenci, ilgili soruya 'bilmiyorum' yanıtını vermiştir. Ayrıca 8 öğrenci, Maraş’ın kahraman unvanını, Sütçü İmam'ın Fransızlarla mücadelesi sayesinde aldığını belirtmişlerdir. Bu konuda K11S1, "Kurtuluş Savaşı yıllarında Maraş, Fransızların işgali altındaydl. Burada bulunan bazı Fransız ve Ermeniler, Maraş halkına işkence yapıyorlardl. Sütçü Imam adındaki bir şahıs Maraş halkına zarar veren insanlarla mücadele etti ve Maraş şehrine kahraman unvanı verildi." şeklinde açıklama yaparken, K12S1 "Sütçü İmam Fransızlara karşı direnmiş ve Fransızların işgaline tepki göstererek Maraş’1 işgalden kurtarmış. Daha sonra Maraş, kahraman unvanı almış."demiştir. Söz konusu durumla ilgili öğrencilerin tarihi bilgilerinde karışıklık olduğu, bunun da yeterli bilgi sahibi olmamalarından kaynaklandığı söylenebilir.

- Maraş destanı ile ilgili düşüncelerin sorulduğu soruya yönelik öğrenci görüşlerinden elde edilen kodlar, literatüre dayanılarak oluşturulmuş üç tema altında (tarihsel anlam, belirgin değerler, yaşamsal ve duygusal anlam) birleştirilmiştir. Temalara ve kodlara ilişkin bilgiler, tablo 3'te yer almaktadır. Kodlar, frekans değerlerine göre sıralanmakla birlikte nitel araştırmaların doğasına uygun olması açısından frekans değerleri verilmemiştir. Ayrıca araştırmada, gerekli görülen yerlerde doğrudan alıntılara yer verilmiştir.

Tablo 3. Maraş Destanına İlişkin Öğrencilerin Görüşleri

\begin{tabular}{ll} 
Temalar & Kodlar \\
\hline \multirow{3}{*}{ Tarihsel anlam } & Halkın direnişi \\
& Maraş'ın düşman işgalinden kurtuluşu \\
& Maraş'ın işgali \\
& Büyük bir zafer \\
\hline & Bağımsılık \\
& Birlik ve beraberlik \\
& Cesaret \\
& Vatan sevgisi \\
& Başarı \\
\hline
\end{tabular}




\begin{tabular}{cl} 
Belirgin değerler & Fedakârlık \\
& Azim \\
& Özgürlük \\
& Dayanışma \\
& Bayrağın dokunulmazlığı \\
& Duyarlılı \\
& Toprağa bağl11ık \\
\hline & İmkânsılılılara rağmen verilen kurtuluş mücadelesi \\
& Gurur duyma/Gururlu olma \\
& Onurlu bir mücadele \\
\hline & Halkın gücü \\
& Baskı ve işkencelere karşı direnme \\
& Anlamlı bir hikâye \\
& İman gücü \\
& Topraklarını düşman işgalinden kurtarmaya çalışan \\
& insanlar \\
anlam & Çevre şehirlere örnek olma \\
\hline
\end{tabular}

'Tarihsel anlam' teması altında, katılımcıların Maraş destanına yönelik tarihsel bakış açısını sunan ifadeler yer almaktadır. Öğrenciler Maraş destanını halkın direnişi, Maraş'ın düşman işgalinden kurtuluşu, işgal edilmesi ve büyük bir zafer olarak nitelendirmişlerdir. 'Belirgin değerler' teması altında, öğrencilerin Maraş'a ve Maraş halkına yönelik atfettikleri değerler bulunmaktadır. Öğrencilerin Maraş destanını bir bağımsızlık mücadelesi, milletin birlik ve beraberlik içerisinde direnişi olarak gördükleri söylenebilir. Ayrıca katılımcılar, Maraş halkının cesaretine, vatan sevgisine, fedakarlığına, azmine, dayanışmasına ve duyarlılığına vurgu yapmışlardır. Bunun yanında Maraş zaferinin büyük bir başarı örneği olduğu, halkın Bayrağın dokunulmazlığına oldukça önem verdiği ve halkın kendi toprağına bağlı olduğu belirtilmiştir. 'Yaşamsal ve duygusal anlam' teması ise öğrencilerin Maraş'ın işgali ve kurtuluşu sırasında yaşanılan duruma dikkat çeken ve öğrencilerin Maraş destanı ile ilgili duygularını yansıtan ifadelerden oluşmaktadır. Öğrenciler, Maraş destanının imkansızlıklara rağmen verilen kurtuluş mücadelesi sonucunda yazıldığını, Maraş işgalinde halkın onurlu bir mücadele verdiğini, yapılan baskı ve işkencelere karşı direndiğini, ne kadar güçlü olduğunu düşmanlara gösteren bir kurtuluş mücadelesi olduğunu belirtmişlerdir. Öğrenciler ayrıca Maraş ve Maraş halkı ile gurur duyduklarını belirtmişlerdir. Bazı öğrenciler, Maraş destanını, topraklarını düşman işgalinden kurtarmaya çalışan, başkalarına bırakmak istemeyen insanlar olarak düşünmektedirler. Bazı öğrenciler ise iman gücünün zaferde etkisi olduğunu belirtmişlerdir. Katılımcılar tarafından Maraş zaferinin çevre şehirlere de örnek olduğu söylenerek Urfa ve Antep’te verilen 
kurtuluş mücadelesine de gönderme yapılmıştır.K10S1 kodlu öğrenci Maraş destanı ile ilgili "Zor şartlar altında olağanüstü durumda silah, mühimmat yokken, düzenli ordu yokken Milletin kuvvetiyle kazanılmıs bir savaştır. Türk Milletinin şahlanış destanıdır." şeklinde açıklamada bulunarak halkın içinde bulunduğu şartlara atıfta bulunmuştur.

3) Sosyal Bilgiler Öğretmenliği Programında öğrenim gören öğrencilerin Kahramanmaraş'ın milli tarih içerisindeki rolüne ilişkin bilgi ve farkındalığın arttırılması için tavsiyeleri nelerdir? sorusuna ilişkin bulgular:

Katılımcılara, gelecek neslin Kahramanmaraş'ın milli tarih içerisindeki rolüne ve kurtuluş mücadelesine ilişkin bilgilerinin ve farkındalıklarının artması için yapılması gerekenlere yönelik önerilerinin neler olduğu sorulmuştur. Öğrencilerin cevaplarında elde edilen kodlar, önerilerin atıfta bulunduğu yere dayanılarak oluşturulmuş üç tema altında (okullara öneriler, yerel yönetimlere öneriler, diğer öneriler) birleştirilmiştir. Temalara ve kodlara ilişkin bilgiler, tablo 4 'te yer almaktadır. Kodlar, frekans değerlerine göre sıralanmakla birlikte nitel araştırmaların doğasına uygun olması açısından frekans değerleri verilmemiştir. Ayrıca araştırmada, gerekli görülen yerlerde doğrudan alıntılara yer verilmiştir.

Tablo 4. Gelecek Neslin Bilgi Ve Farkındalıklarını Arttırmaya Yönelik Öneriler

\begin{tabular}{|c|c|}
\hline Temalar & Kodlar \\
\hline \multirow{10}{*}{ Okullara öneriler } & Tiyatro gösterimi yapilmalı \\
\hline & Tarihi yerlere ve müzelere geziler düzenlenmeli \\
\hline & Çeşitli etkinlikler düzenlenmeli \\
\hline & Video, belgesel, film, çizgi film vb. sanatlardan sıkça yararlanılmalı \\
\hline & Öğrencilere etkinliklerde aktif rol verilmeli \\
\hline & Derslerde Maraş'in kurtuluşuna daha fazla yer verilmeli \\
\hline & Kitaplarda Maraş'in kurtuluşuna daha fazla yer verilmeli \\
\hline & Okul içinde Maraş ile ilgili konferanslar düzenlenmeli \\
\hline & Toplumun ileri gelenleriyle söyleşiler yapilmalı \\
\hline & Maraş'in kurtuluşu konulu kompozisyon, şiir vb. yarışmalar düzenlenmeli \\
\hline \multirow{9}{*}{$\begin{array}{c}\text { Yerel yönetimlere } \\
\text { öneriler }\end{array}$} & Kurtuluş günü etkinlikleri arttırilmalı \\
\hline & Maraş'in kurtuluşu ile ilgili halka açık ücretsiz tiyatro gösterimleri olmalı \\
\hline & Şehrin uğrak yerlerine Maraş'in kurtuluşu ile ilgili posterler/afişler asılmalı \\
\hline & Kurtuluş törenlerine okulların aktif katılımı sağlanmalı \\
\hline & Tanıtımlar daha çok yapılmalı \\
\hline & Önemli meydanlara açık hava sinemaları kurulmalı \\
\hline & Tarihi yerler restore edilmeli \\
\hline & Ücretsiz müze gezileri yapılmalı \\
\hline & Maraş ile ilgili dergi çıkartilmalı \\
\hline \multirow{5}{*}{ Diğer öneriler } & Maraş’in kurtuluşu ile ilgili filmler/diziler çekilmeli \\
\hline & Konferanslar düzenlenmeli \\
\hline & Maraş’in kurtuluşu ile ilgili belgeseller çekilmeli \\
\hline & Aile bilinçlendirme etkinlikleri düzenlenmeli \\
\hline & 12 Şubat günü resmî tatil yapilmalı \\
\hline
\end{tabular}




\section{KSÜSBD Milli Mücadelenin 100. Yılında Kahramanmaraș Özel Sayısı}

'Okullara öneriler' teması altında, öğrencilerin hem ders dışı hem de ders içi faaliyetlerine yönelik öneriler yer almaktadır. Katılımcıların ders dışı faaliyetlere yönelik önerilerinde ilk siralarda tiyatro gösterimleri, tarihi yerlere ve müzelere gezilerin düzenlenmesi yer almaktadır. Katılımcıların yine büyük bir çoğunluğu okullarda çeşitli etkinlikler düzenlenmesi gerektiğini belirtmekle beraber bu etkinlerin neler olduğuna dair ayrıntılı bilgi sunmamışlardır. Ders dışı faaliyet önerilerinden diğerleri, toplumun ileri gelenleriyle söyleşiler ve Maraş ile ilgili konferanslardır. Ders içi faaliyetlere yönelik önerilerde ise ilk sıralarda derslerde Maraş ile ilgili video, belgesel, film, çizgi film gibi görsellerin sıklıkla öğrencilere izlettirilmesi, derslerde ve kitaplarda Maraş'ın kurtuluşuna daha fazla yer verilmesi olduğu görülmüştür. Ayrıca katılımcılar Maraş'ın kurtuluşu konulu kompozisyon, şiir vb. yarışmalar düzenlenmesini önermişlerdir.

'Yerel yönetimlere öneriler' teması altında ilk sırayı, 12 Şubat günü yapılan kurtuluş bayramı etkinliklerinin arttırılması yer almıştır. Katılımcılar, halkın bilinçlendirilmesini önemsemektedir. Bu sebeple Maraş'nn kurtuluşu ile ilgili halka açık ücretsiz tiyatro gösterimlerinin olmasını, şehrin uğrak yerlerine yine Maraş'in kurtuluşu temalı posterlerin/afiş̧lerin asılmasını, önemli meydanlara açık hava sinemalarının kurulmasını, tarihi yerlerin restore edilerek halkın hizmetine sunulmasını, ücretsiz müze gezilerinin düzenlenmesini önermektedirler. Ayrıca okullarla iş birliğinin arttırılarak kurtuluş törenlerine okulların aktif katılımının sağlanmasını yerel yönetimlerden beklemektedirler. Katılımcıların yerel yönetimlere diğer önerileri ise Maraş'ın tanıtımının daha çok yapılması ve Maraş ile ilgili dergi çıkartılması olmuştur.

"Diğer öneriler" teması altında ise diğer iki temayı içermediği düşünülen ifadeler yer almaktadır. Maraş'ın kurtuluşu ile ilgili filmlerin, dizilerin ve belgesellerin çekilmesi, sıklıkla önerilen ifadeler olmuştur. Önceki yıllarda çekilen ve devlet kanalında yayınlanan bir dizinin, Kahramanmaraş'ın tanıtımında önemli rol oynadığı bilinmektedir. Bu konuda K10S1, "Ülke çapında tanınmış yönetmen ve oyuncuların desteğiyle sinema filmi yapılması çok etkileyici olur bence." diyerek sanatsal etkinliklerin önemine dikkat çekmiştir. Katılımcılar Maraş ile ilgili konferanslar düzenlenmesi gerektiğini belirtmişlerdir. Ayrıca öğrencilerden önce ailelerin Maraş ile ilgili bilinçlendirilmesi gerektiğini düşünerek bu konuda etkinlikler düzenlenmesini ifade etmişlerdir. Ayrıca 12 Şubat gününün resmî tatil yapılması bir diğer öneridir. Söz konusu önerilere bakıldığında, katılımcıların Kahramanmaraş'ın il dışında da tanınırlığının artmasını istedikleri söylenebilir.

\section{TARTIŞMA, SONUÇ ve ÖNERILER}

"Türk Milli Kurtuluş Mücadele"sinin dönüm noktası olan "Kahramanmaraş Savunması"na ilişkin olarak yapılan bu araştırma sonucunda, ulaşılan bilgi ve 
bulgulara göre, özellikle de aydın gençler olarak adlandırılabilecek üniversite gençliğinin bu konuya ilişkin hâkimiyetlerinin az olduğunun tespit edilmesi son derece düşündürücüdür. Özellikle araştırma kapsamında görüşlerine başvurulan bu gençlerin Sosyal Bilgiler Öğretmeni olarak Milli Eğitim Bakanlığı (MEB) bünyesinde görev yapma hedefiyle lisans eğitimine devam eden ve görev alanı öncelikli olarak "milli tarih, milli kültür, milli kimlik, milli şuur vb. bilgi ve kavramların" öğrencilere aktarımı olacak olan aday öğretmenler olması ise endişe verici bir durumdur. Hedefi bireylere istendik davranış kazandırma olan eğitim süreci açısından da bu olaya yaklaşıldığında genelde "Milli Tarih Öğretimi”"ne özelde ise "Kahramanmaraş Savunması"na ilişkin hedef ve kazanımlara yeterince ulaşılamadığı söylenebilir.

Tespit edilen bilgi ve bulgulara göre gençlerin "Kahramanmaraş Kurtuluş Destanı"na ilişkin bilgileri maalesef ya yeterince öğrenememiş, ya unutmuş, ya unutturulmuş ve/veya yeterince hatırla(ya)mıyor durumda olmaları yönündedir. $\mathrm{Bu}$ da milli kimlik / milli şuur inşası noktasında eğitim sürecimizin sorgulanması ve yeni yöntem ve metotların tespit edilerek tarih öğretiminin yeniden tasarlanması gerektiğini gözler önüne sermektedir.

Ulaşılan sonuçları çeşitli araştırmalar ışığında tartışılacak olursak;

- Maraş'ın kaç yılında işgal edildiğine ilişkin katılımcıların \%53'ü ile yarısından fazlası cevabı 'bilmediğini' ifade etmiştir. Ailelerin yaşadıkları illere göre cevaplar karşılaştırıldığında, Maraş'ta yaşayan 48 öğrenciden yalnızca dört öğrencinin (\%8) 1919 diyerek doğru cevabı verdiği görülmüştür. Başka bir ifadeyle ailesiyle birlikte Maraș'ta yașayan katılımcıların \%92'si Maraș'ın hangi yllda ișgal edildiğini bilmemektedirler.

- Maraş'ta yaşayan 48 öğrenciden 5'inin (\%10) Maraş'in ne kadar süre işgal altında kaldığı bilgisine sahip olduğu görülmekte iken 43’ünün (\%90) ne kadar süre işgal altında kaldığı bilgisine sahip olmadığı tespit edilmiștir. Ailelerin yaşadığı il değişkeni açısından da durum incelendiğinde, Maraş'ta yaşayan 48 öğrenciden 15'inin (\%31) Maraş'ın kimler tarafindan işgal edildiği bilgisine sahip olduğu görülmekte iken 33'ünün (\%69) bunu bilmediği görülmektedir. Toplam öğrenci içerisinde bu durum katılımcıların \%75'inin bunu bilmediği şeklinde tespit edilmiştir.

- Maraş'ın işgalinin ne kadar sürdüğüne ilişkin soruya 54 öğrenci (\%57) 'bilmiyorum' cevabını vermiștir. Bilmiyorum cevabı veren öğrencilerin (25'inin) yaklaşık yarısının, ise ailesinin Maraş'ta yaşadığı görülmüştür. Bulguların geneline bakıldığında öğrencilerin tarih bilgilerinin zayıf olduğu söylenebilir.

- Öğrencilerden yalnızca 18'i (\%19) Maraş'ın kurtuluşu ile ilgili bir etkinliğe katıldığını belirtmiştir. Kalan 76 öğrenci ise hiçbir etkinliğe 


\section{KSÜSBD Milli Mücadelenin 100. Yılında Kahramanmaraș Özel Sayısı}

katılmadıklarını söylemiştir. Bu oran katılımcıların \%81'ine tekabül ettiği tespit edilmiştir.

- Öğrencilerin Maraş'ın kurtuluşu ile ilgili bilgileri en çok okuldan $(f=61)$, sirasiyla aileden $(f=31)$, sosyal çevreden $(f=25)$, sosyal medyadan $(f=17)$, üniversiteden ( $f=11)$, basından $(f=8)$, belediye etkinliklerinden $(f=7)$ öğrendikleri görülmüştür. Bunlar dışında müze gezilerinden de $(f=3)$ öğrendiğini belirten öğrencilere rastlanmıştır. Ayrıca buna ilişkin bilgilerin okulda genellikle tarih disiplini içerikli derslerden veya ders kitaplarından edinildiği öğrenciler tarafından belirtilmiştir. Yıldız (2003) makalesinde; aile tarihi, ziraat tarihi, yerel tarih ve okul tarihi gibi benzeri tarih türleri ve tarih çalışmaları öğrencilerde tarih bilincinin ve sevgisinin oluşmasını sağlayacağını belirtmektedir. Altun (2016) araştırmasında; Çocuklar anne ve babalarından, büyükanne ve büyükbabalarından, kardeşlerinden, diğer akrabalarından ve akranlarından tarihi ögrrenmekte ve yine bu sosyal çevresi sayesinde tarihe olan ilgisi artmaktadır. Yine Altun (2016) araştırmasında; tarih bölümü öğrencilerinde herhangi bir tarihi mekânı gezmek gibi daha gerçekçi olan (realistik merak) bir deneyimsel merakın öne çıktığını bildirmektedir.

- Okulda genellikle tarih disiplini içerikli derslerden veya ders kitaplarından edinildiği belirtilmiştir. Bilgi içerikli sorulara verilen yanıtlara ilişkin bulgularla birlikte ele alındığında, okulda öğrenilen bilgilerin kalıcılığının sorgulanması gerektiği söylenebilir. K16S1 kodlu öğrenci "Okullarda ders içeriklerinde anlatıldı fakat aklımda kalmasını sağlayacak kadar değil" diyerek söz konusu yorumu desteklemektedir. Arkadaş çevresi, sokak adlarından vb. ifadeler ise sosyal çevreye dâhil edilmiştir. K41S2 kodlu öğrenci bu konuda "Yerlere ve bölgelere verilen isimler bir hikâye ve geçmişi sezdiriyor" diyerek sokak adlarının bile tarihi bilgileri öğrenme merakı oluşturduğuna dikkat çekmiştir. Tarihi merakı ön plana çıkaracak bir yaklaşım tarzıyla öğretim yapılmalıdır. Konuya ilişkin içeriklerde acilen güncelleştirmeler yapılmalıdır. Akılda kalıcılığın sağlanamamasının sebebini ise, Karabağ ve Aydoğan, (2015) yaptıkları araştırmada; tarih öğretimi ile ilgili problemin tarihin içeriğinden değil, sunumundan kaynaklandığı söylenebilir. İçerikler öğrenci merkezli olarak ve öğrencilerin ilgi ve ihtiyaçlarına göre düzenlenmelidir. Altun (2016) makalesinde; öğrencilerin ilgileri ve yeterlikleri göz ardı edilmemesi gerektiğini vurgulamıştır. Özmen, Er ve Ünal (2014) araştırmalarında; etkili öğretim için öğrenci merkezli eğitim etkinlikleriyle ve materyallerle tarih öğretiminin yapılması gerektiğine vurgu yapmışlardır. Aktif yaklaşımlar benimsenerek tarih öğretimi ve aktarımı yapılmalıdır. Öğrencilerin konuya ilişkin araştırma yetileri artırılması da kalıcı izli öğrenme yaşantıları için önem arz etmektedir. Karabă ve Aydoğan (2015) makalelerinde; öğrencilerin kendine sunulan bilgilerin pasif alıcısı değil, tarihsel araştırma yapma kapasitesine sahip kişiler olduklarını aktarmaktadırlar. Altun (2016) makalesinde; özellikle birinci elden kaynakları 
çalışmanın, şaşırtıcı nesne, imge ve metinleri incelemenin, tarih kitaplarını okumanın ve hikâyeci anlatımı kullanmanın öğrencilerin tarih merakını canlandırdığı vurgulamıştır. Yıldız (2003) araştırmasında; öğrencinin aktifliğinin sağlanması için, oyunlar, tartışmalar, eleştirel değerlendirmeler, grafikler, haritalar, değişik kaynaklar kullanması gerektiğini belirtmektedirler. Ayrıca Yıldız (2003) araştırmasında; tarih öğretiminde konuların gelecek ve günümüzle ilişkilendirilerek öğretilmesi gerektiğine vurgu yaparken bir yandan da ögrenciler adeta anlatılan zamanın şartlarına götürülmeli ve o zamanda yaşadıkları hissini verilerek öğretimin yapılması gerektiğini belirtmektedir. Altun (2016) makalesinde; aidiyet bağlamında katılımcıların bazı tarihi karakter, olay, dönem ya da mekânı sahiplendikleri ve bunlara yönelik sempatik merak oluştuğu görülmüş̧ür.

- Öğrencilere okulda yapılan Maraş'ın kurtuluşuna yönelik etkinliklerden hafizasında kalanlar sorulmuştur. İfade sıklığına göre sırasıyla öğrenciler, tiyatro gösterimi $(f=22)$, şiir okuma etkinliği $(f=22)$, metin, destan vb. okuma etkinliği $(f=4)$, günün anlam ve önemine dair ögretmenlerin konuşmaları $(f=4)$, çete kıyafetleri ile yürüyüs yapmak $(f=4)$, drama/canlandırma etkinliği $(f=3)$, folklor oyunları $(f=2)$, kısa film gösterimi $(f=1)$, koro halinde okunan şarkılar $(f=1)$ gibi etkinliklerin hafızalarında kaldığını belirtmişlerdir. Elde edilen bulgulara göre, öğrenciler en fazla tiyatro gösterimini ve şiir okuma etkinliklerini; en az ise folklor, kısa film gösterimi ve koro etkinliklerini hatırlamaktadırlar. Altun (2016) makalesinde; Yeager ve Terzian (2007)'dan yaptıkları alıntıda tarih ilgisini sınıf içi ve sınıf dışı tarih ilgisi olarak ikiye ayrıldığını belirtmişlerdir.

- Katılımcıların Kahramanmaraş'ın Kurtuluşuyla ilgili katılımcıların; konuya ilişkin olarak \% 91'inin "Kitap" okumadıkları, \% 87'sinin "Şiir" okumadıkları, \%83'ünün "Tiyatro gösterisi” izlemedikleri, \%90'ının "Film” izlemedikleri, \%95'inin de "Çizgi Film” izlemedikleri ortaya çıkmıştır. Özmen vd. (2014) yaptıkları araştırma sonucunda, tarihi mekânlardan sonra öğrencilerin en keyif aldıkları sunum şeklinin tarihi filmler olduğu görülmüş, ayrıca öğrencilerin tarihi filmlere olan güveninin fazla olduğu tespit edilmiştir. Yine Özmen vd. (2014) göre, öğretim sürecine ne kadar çok duyu organı katılırsa öğrenmenin kalıcılığı da o oranda artmaktadır filmler birden fazla duyu organını işe koşması sebebiyle etkili öğrenme araçlarıdırlar. Bunların yanında etkili öğretme araçlarından biri de filmlerdir. Film vasıtasıyla tarih dersleri daha ilginç ve zevkli hâle getirildiği gibi öğrencilerin geleneksel yollarla kazanması zor olan üst düzey düşünme becerileri, sentez, analiz ve değerlendirme bu yolla kazandırılabilir. Yıldız (2003), tarih derslerinde görsel iletişim araçlarına yer verilmeli, tepegöz, slayt, bilgisayar, televizyon etkin olarak kullanılmalıdır.

- Ancak katılımcıların \%63 oranıyla yaklaşık üçte ikisinin konuyla ilgili müze ziyaretine gittikleri tespit edilmiştir. Altun (2016) göre, "realistik/gerçekçi 


\section{KSÜSBD Milli Mücadelenin 100. Yılında Kahramanmaraș Özel Sayısı}

tarih merak1 ise bireyin geçmişte yapılmış, bireysel ya da toplumsal olarak günümüzde önemli (ya da ilginç, sıradışı olan) kabul edilen ve varlığını devam ettiren tarihi yer veya mekânları ziyaret etme isteğiyle ortaya çıkan bir merak türüdür. Savaş alanı, müze, mabet gibi bu tarihi yer veya mekânları gezmek istemek gibi gerçekçi bir deneyim isteğine dayanmaktadır." Yıldız (2003) araştırmasında; Şimşek (2003)'ten aktardıklarına göre, “en etkili öğretim yöntemi olan yaparak-yaşayarak öğrenme yöntemi tarih eğitiminde kullanılması zor olacağından; sözel ve görsel semboller, radyo ve ses kayıtları, gösterim ve oyunlaştırma, sergiler ve müzeler vs. gibi alternatif yöntemler tercih edilerek ders daha verimli hâle getirilebilir" Öğrencilerin tarihi yeniden konuşup, kendi yorumlarını yapması, derslerde; radyo, kaset, CD kullanılması, projeler hazırlanması, müzeleri ve tarihi yerleri gezmesi gibi öğrenciyi aktif hale sokacak davranışların derslerde etkili kılınması gerekmektedir.

- Maraş halkına işgal dönemindeki mezalimler hakkında görüş ve bilgilerinin sorulduğu soruya ilişkin verilen cevaplar kullanım sıklığına göre yapılan mezalimler, kadınlara taciz $(\mathrm{f}=20)$, halka zulüm ( $\mathrm{f}=16)$, halkın malını yağmalama/malına zarar verme ( $\mathrm{f}=9$ ), halka şiddet uygulama ( $\mathrm{f}=8$ ), milli ve dini duygulara saygısızlık $(\mathrm{f}=7)$, halkın yaşayışına müdahale etme $(\mathrm{f}=7)$, sivil halka işkence ( $\mathrm{f}=7$ ), halka bask1 ve tehdit $(\mathrm{f}=7)$, sivil halk1 öldürme $(\mathrm{f}=6)$, halkı aşağılama/köle gibi görme ( $\mathrm{f}=4)$ ve tecavüz $(\mathrm{f}=4)$ şeklinde sıralanabilir. Bununla birlikte 94 öğrenciden 46'sı söz konusu soruya 'bilmiyorum' cevabını vermiştir. Öğrencilerin neredeyse yarısının (\%49) milli tarih konusunda farkındalıklarının zayıf olduğu söylenebilir.

\section{ÖNERILER}

Araştırma bulgularından hareketle öneriler şöyle sınıflandırılmıştır: Genel Öneriler, okullara yönelik öneriler, yerel yönetimlere yönelik öneriler ve diğer öneriler olmak üzere:

\section{Genel Öneriler:}

- Öncelikle bu konuya ilişkin olarak tüm eğitim kademelerinde olmak üzere gerekli önlemler zaman geçirilmeden alınmalıdır.

- İnsanımızın zihin dünyasında milli kimlik / milli şuur inşası sürecinde nelerin eksik kaldığı ve nelerin yapılması gerektiğine ilişkin olarak acil bir politika belgesi oluşturulmalıdır.

- Geleneksel yöntemden ziyade oyun yöntemiyle tarih öğretimi yapılması sağlanmalıdır. Oyun yöntemi genel tarih öğretiminin yanı sıra yerel tarih öğretiminde kullanılmalıdır. Soyut olan tarih konularının öğrenilmesi sürecinde ögrencilerin oyun içinde rol alarak kalıcı izli davranış değişikliği sağlanabilir. 
- Yapılandırmacı yaklaşımın özüne uygun olarak, tarih öğretiminde geleneksel yöntem yerine aktif yöntemler tercih edilmelidir. Aktif yöntemler içinde yer alan öğrencinin öğrendikleri daha kalıcı olacaktır.

- Tarihi içeriklere sahip nitelikli film ve dizilerin yüksek izlenme oranına sahip olmaları nedeniyle "Maraş Destanı"na ilişkin film ve diziler yapılmalıdır.

- Ayrıca araştırma bulgularından hareketle, tarihsel olayları odağa alan nitelikli romanların ve popüler tarih konulu dergilerin toplum katında revaç bulması nedeniyle yazarlar ve şairler şehri olan Kahramanmaraş'lı edebiyatçılar ve şairler başta olmak üzere ülke çapında bu konuya ilişkin yarışmalar tertip edilerek; romanların, tiyatro oyunlarının, özel dergilerin ve şiirlerin yazılması sağlanmalıdır.

- Gençler tarafindan büyük ilgiyle oynanan bilgisayar oyunlarına "Maraş Destanı"na ilişkin oyun ve oyunlar eklenmesinin sağlanması bu destana ilişkin mekân, kişi ve olayların öğrencilerin zihinlerinde yer etmesine olanak sağlayabilir.

\section{Okullara yönelik öneriler:}

- Tiyatro gösterimi yapılmalı,

- Tarihi yerlere ve müzelere geziler düzenlenmeli,

- Çeşitli etkinlikler düzenlenmeli,

- Video, belgesel, film, çizgi film vb. sanatlardan sıkça yararlanılmalı,

- Öğrencilere etkinliklerde aktif rol verilmeli,

- Derslerde Maraş'ın kurtuluşuna daha fazla yer verilmeli,

- Kitaplarda Maraş'ın kurtuluşuna daha fazla yer verilmeli,

- Okul içinde Maraş ile ilgili konferanslar düzenlenmeli,

- Toplumun ileri gelenleriyle söyleşiler yapılmalı,

- Maraş'in kurtuluşu konulu kompozisyon, şiir vb. yarışmalar düzenlenmeli.

\section{Yerel yönetimlere yönelik öneriler:}

- Kurtuluş günü etkinlikleri arttırılmalı, 


\section{KSÜSBD Milli Mücadelenin 100. Yılında Kahramanmaraș Özel Sayısı}

- Maraş'ın kurtuluşu ile ilgili halka açık ücretsiz tiyatro gösterimleri olmali,

- Şehrin uğrak yerlerine Maraş'ın kurtuluşu ile ilgili posterler/afişler asilmal1,

- Kurtuluş törenlerine okulların aktif katılımı sağlanmalı,

- Tanıtımlar daha çok yapılmalı,

- Önemli meydanlara açık hava sinemaları kurulmalı,

- Tarihi yerler restore edilmeli,

- Ücretsiz müze gezileri yapılmalı,

- Maraş ile ilgili dergi çıkartılmalı.

Diğer öneriler:

- Maraş'ın kurtuluşu ile ilgili filmler/diziler çekilmeli,

- Konferanslar düzenlenmeli,

- Maraş'ın kurtuluşu ile ilgili belgeseller çekilmeli,

- Aile bilinçlendirme etkinlikleri düzenlenmeli,

- 12 Şubat günü resmî tatil yapılmalı.

\section{KAYNAKÇA}

Akbaba, Bülent (2008), “Atatürk İlkeleri ve İnkılâp Tarihi Dersinin Öğretiminde Karşılaşılan Sorunlar Gazi Üniversitesi Örneği”, Gazi Akademik Bakış, Vol. 1, No: 2, ss. 177-197.

Altun, Adnan (2016), “Tarih Merakına Yönelik Bir İnceleme: Fen-Edebiyat Fakültesi (AİBÜ) Tarih Bölümü Öğrencilerinin Tarihe Dair Merakları”, Turkish History Education Journal, Vol. 5, No: 2, ss. 390436, https://dergipark.org.tr/tr/pub/tuhed/issue/26594/279933.

Arsal, Sadri Maksudi (1972), Milliyet Duygusunun Sosyolojik Esasları, Ötüken Yayınevi, İstanbul. 
Ata, Bahri (2000), “İsmail Hakkı Baltacıoğlu ve Tarih Öğretimi”, Türk Kültürü Dergisi, 450, ss. 590-602.

Ata, Bahri (2015), “Tarih Derslerinde Yerel Tarih, Müze ve Ören Yerlerinin Kullanımı”, Tarih Öğretim Yöntemleri (2. Baskı), (Ed. Muammer Demirel), Pegem Akademi Yayıncılık, Ankara, ss. 74-87

Bal, Mehmet Suat (2010), Türkiye'de Tarih Öğretimin Sorunları ve Çözüm Yolları Konusunda Öğretmen Adayı ve Öğretmen Görüşlerinin Karşılaştırılması”, Mustafa Kemal Üniversitesi Sosyal Bilimler Dergisi, Vol. 8, No:1, ss.371-378.

Biletska, Yuliya - Şahin, Cemile - Şükür, İsmail (2014), "Kolektif Hafıza ve Milli Kimlik Bağlamında Türkiye'de Resmi Tarih Yazıcılığı", Itobiad: Journal of the Human \& Social Science Researches, Vol. 3, No: 1, ss. 94-116.

Christien, Larry B. - Johnson, R. Burke - Turner, Lisa A. (2015), Araştırma Yöntemleri, Desen ve Analiz, (Çev. Ahmet Aypay), Anı Yayıncılık, Ankara.

Çakmak, Zafer ve Bulut, Birol (2013), “2004 Sosyal Bilgiler 7. Sınıf Öğretim Programı ve Tarih Bilinci”, Pamukkale Üniversitesi Eğitim Fakültesi Dergisi, 34, ss. 147-156, DOI: 10.9779/PUJE589.

Doğan, Orhan (2007), "Millî Mücadele'de Maraş ve Mustafa Kemal”, İstanbul Üniversitesi Edebiyat Fakültesi, Tarih Dergisi, S. 42, ss. 207-230.

Eyicil, Ahmet (2003), “I. Dünya Savaşı ve Kurtuluş Mücadelesi Sırasında Maraş’ta Ermeni Mezalimi”, Belleten, Cilt XVII, S. 250, ss. 911-949.

Gözler, Kemal (2001), "Devletin Bir Unsuru Olarak 'Millet' Kavramı", Türkiye Günlügü, S.64, ss. 108-123.

Karabağ, Gülin ve Aydoğan, Okan (2015), “Oyun Yöntemiyle Tarih Öğretiminin Öğrenci Erişisine ve Kalıcılığa Etkisi”, Turkish History Education Journal, Vol. 4, No: 1, ss. 67-88, DOI: 10.17497/tuhed.185623.

Karasar, Niyazi (2019), Bilimsel Araştırma Yöntemi: Kavramlar, İlkeler, Teknikler (34. Basım), Nobel Yayınc1lık, Ankara.

Kaya, Ramazan (2015), “Tarih Öğretiminin Amaçları”. Tarih Öğretim Yöntemleri (2. Baskı), (Ed. Muammer Demirel), ss. 37-54, Pegem Akademi Yayıncilık, Ankara. 
Kılınç, Mustafa (2018), “Millî Mücadelede Maraş’ta Siyasi ve Sosyal Gelişmeler ve Millî Mücadelede Maraş Şehitleri”, Asia Minor Studies, Vol. 6, No: 12, ss. 171-189.

Millî Eğitim Bakanlığı. (2005). Sosyal bilgiler öğretim programı. http://ttkb.meb.gov.tr/program2.aspx (15.11.2019).

Millî Eğitim Bakanlığı. (2018). Sosyal bilgiler öğretim programı. http://mufredat.meb.gov.tr (15.11.2019).

Öner, Necati (1986), Milli Zihniyet ve Milli Birlik, Türk Kültürü Araştırma Enstitüsü, Ankara.

Özmen, Cengiz - Er, Harun - Ünal, Fatma (2014), “Televizyon Dizilerinin Tarih Bilinci Üzerine Etkisi 'Muhteşem Yüzyıl Dizisi Örneği’”, Mustafa Kemal Üniversitesi Sosyal Bilimler Enstitüsü Dergisi, Vol. 11, No: 25, ss. 409-426.

Safran, Mustafa (Ed.) (2010), Tarih Nasıl Öğretilir? (1.Baskı), Yeni İnsan, İstanbul.

Smith, Anthony D. (2002), “When is a Nation”, Geopolitics, Vol. 7, No: 2, ss. 5-32, DOI: $10.1080 / 714000928$.

Smith, Anthony D. (1991), National Identity, University of Nevada Press, Reno.

Sungu, İhsan (1927), "Tarih Tedrisatı Hakkında", Terbiye Dergisi, Cilt: 2, Sayı: 8, ss. 2-8'den aktaran Bahri Ata, "Tarih Öğretimi Hakkında", Millî Eğitim Dergisi, 153/154, 2002, ss. 52-59.

Şıvgın, Hale (2009), “Ulusal Tarih Eğitiminin Kimlik Gelişimindeki Önemi”, Gazi Akademik Bakış, 4, ss. 35-52.

Şimşek, Ufuk ve Ilgaz, Selçuk (2010), “Küreselleşme ve Ulusal Kimlik”, Atatürk Üniversitesi Sosyal Bilimler Enstitüsü Dergisi, Vol. 9, No: 1, ss. 189-199.

Ünalp, F. Rezzan (2018), “Birinci Dünya Harbi Sonunda Maraş'ın İtilaf Devletlerince İşgali ve Maraş Savunması”, Gazi Akademik Bakış, Vol. 11, No: 22, ss. 205-235.

Yıldız, Özgür (2003), “Türkiye'de Tarih Öğretiminin Sorunları ve Çağdaş Çözüm Önerileri”, Erciyes Üniversitesi Sosyal Bilimler Enstitüsü Dergisi, Vol. 1, No: 15, ss. 181-190. 
İnternet Kaynaklar1

https://ansiklopedi.46.web.tr/abdal-halil-aga/ (05.12.2019).

http: www.kahramanmaras.ktb.gov.tr (05.12.2019).

http: www.youtube.com/watch?v=YgB7c5QlVys\&t=1s (05.12.2019).

https://sozluk.gov.tr/ (10.11.2019).

http: www.kahramanmaras.bel.tr (10.11.2019). 